\title{
DA SOLIDÃO À CAPACIDADE DE ESTAR SÓ NA PRESENÇA DE ALGUÉM: PERCURSOS CLíNICOS A
} PARTIR DA PERSPECTIVA DE WINNICOTT

Nadja Nara Barbosa Pinheiro

Universidade Federal do Paraná

Maria Vitória Campos Mamede Maia

Universidade Federal do Rio de Janeiro
Recebido em: 24/07/2020

$1^{a}$ revisão em: 01/10/2020

Aceito em: 30/10/2020

\section{RESUMO}

Objetivando tematizar a importante passagem no desenvolvimento emocional, proposta por Winnicott, da solidão à capacidade de estar sozinho (na presença de alguém), o artigo inicia apresentando, sucintamente, a perspectiva teórica do autor sobre a questão. Em seguida, descreve dois percursos clínicos nos quais a condução do trabalho terapêutico permitiu a abertura de possibilidades de vivências construtivas à solidão original, trazida ao setting, pelas pacientes, como fundamento do desespero e da angústia.

Palavras-chave: solidão; clínica psicanalítica; Winnicott. 


\section{FROM LONELINESS TO THE ABILITY TO BE ALONE IN THE PRESENCE OF SOMEONE: CLINICAL PATHWAYS FROM WINNICOTT'S PERSPECTIVE}

\section{ABSTRACT}

Aiming to focus on the important passage in emotional development, proposed by Winnicott, from loneliness to the ability to be alone (in the presence of someone), the article begins by briefly presenting the author's theoretical perspective on the issue. Then, it describes two clinical paths in which the conduct of the therapeutic work allowed the opening of possibilities of constructive experiences to the original loneliness brought to the setting, by the patients, as the foundation of despair and anguish.

Keywords: loneliness; psychoanalytic clinic; Winnicott. 


\section{DESDE LA SOLEDAD HASTA LA CAPACIDAD DE ESTAR SOLO EN PRESENCIA DE ALGUIEN: VÍAS CLÍNICAS DESDE LA PERSPECTIVA DE WINNICOTT}

\section{RESUMEN}

Con el objetivo de centrarse en el importante paso en el desarrollo emocional, propuesto por Winnicott, desde la soledad hasta la capacidad de estar solo (en presencia de alguien), el artículo comienza presentando brevemente la perspectiva teórica del autor sobre el tema. Luego, describe dos caminos clínicos en los cuales la realización del trabajo terapéutico permitió la apertura de posibilidades de experiencias constructivas a la soledad original traída al setting, por los pacientes, como la base de la desesperación y la angustia.

Palabras clave: soledad; clínica psicoanalítica; Winnicott. 


\section{INTRODUÇÃO}

Em dezembro de 2019, um processo de mudança, inesperado, inusitado e angustiante foi disparado. A mutação em um conhecido vírus - corona - se apresentou em sua forma letal. De rápido contágio e com um índice de mortalidade relativamente alto, o mundo foi surpreendido e percebeu-se que os serviços de saúde de todos os países eram precários para o combater. A vida das pessoas se transformou em menos de um mês. Notícias diárias de mortes em um número incomensurável impeliram as cidades a se fecharem e determinarem a seus cidadãos que permanecessem trancados em casa. Muitos, sozinhos, sem poderem ver seus amigos, colegas de trabalho e familiares. Isolados em suas casas, depararam-se com a solidão. A partir daí, quer seja nas redes sociais, quer seja em conversas domiciliares, tornou-se bastante evidente a dificuldade das pessoas em lidarem com o fato de estarem sós em suas casas. Muitos declararam sentirem-se desorientados, desorganizados, deprimidos e desamparados.

Não é pouco importante o fato de que tal isolamento tenha sido mandatório pelo enfrentamento de uma doença desconhecida e sem que a medicina ainda tenha um arsenal de medicamentos e vacinas que possa enfrentá-la. Ou seja, o perigo real e iminente do adoecimento e da morte, por si só, já nos parece suficiente para produzir um abalo afetivo. No entanto, o que nos parece digno de nota e de atenção é o fato de que o enfrentamento do distanciamento social, em si, seja indicado pelas pessoas como disparador da sensação de angústia e desamparo. Isto é, tal queixa nos parece importante, pois mesmo antes da pandemia ter se instalado, ela já era bastante frequente em nosso trabalho clínico cotidiano. Nele, é comum ouvirmos de nossos pacientes que eles possuem uma grande dificuldade em lidar com a solidão. Nos momentos em que eles vivenciam essa situação, o medo e a angústia são os sentimentos que, costumeiramente, emergem.

Nesse sentido, nos parece importante destacar que Winnicott, a partir de sua escuta clínica, também esteve preocupado com essa questão e, no Congresso Internacional organizado pela International Psychoanalitc Association, no ano de 1957, apresentou a seus colegas uma palestra sobre o assunto. No ano seguinte, tomando como base o que havia apresentado nessa ocasião, ele publicou, no International Journal of Psychoanalysis, um artigo intitulado "A capacidade para estar só" (Winnicott, 1958/1982a). O interessante é que nele, o autor toma um caminho inusitado para discorrer sobre o tema. E, distanciando-se da maioria dos estudos psicanalíticos de sua época, que focalizavam o medo ou o desejo de se estar só, Winnicott apresenta a tese de que devemos prestar atenção à construção de uma capacidade subjetiva para se estar só. Essa capacidade fornecerá bases emocionais sustentáveis para que aproveitemos a solidão de forma criativa e sem a necessidade de recorrermos a defesas psíquicas rígidas, tais como o isolamento, a angústia ou o retraimento. Exatamente por sua relevância, o autor destaca, nesse artigo, que a capacidade para se estar só seja uma das mais importantes conquistas que o ser humano pode alcançar em seu processo de desenvolvimento emocional. 
Em nossa opinião, para melhor compreendermos o que está sendo proposto pelo autor, precisamos relacionar sua asserção à sua teoria sobre o processo de amadurecimento afetivo. Para construir sua proposta, Winnicott (1958/1982a) parte de dois princípios básicos: o pensamento paradoxal e o fato de que, no início dos inícios, o bebê está inserido em uma fase de dependência absoluta em relação ao ambiente/mãe - que o gerou e o acolheu após o nascimento. Esse estado especial de dependência determina que bebê/mãe/ambiente constituam uma unidade/múltipla/indiferenciada. O paradoxo se coloca, pois, se por um lado o bebê está imerso em uma solidão fundamental, ele só o está porque há alguém ao seu lado, dele cuidando. Portanto, a solidão essencial, dos tempos imemoriais, só é possível se acompanhada pela presença vital de um outro ser humano.

Nesse sentido, acreditamos que as ideias propostas pelo autor nesse artigo de 1958 se relacione intimamente com outros três artigos de sua autoria. No primeiro deles, intitulado "Teoria do relacionamento paterno-infantil", Winnicott (1960/1982b) destaca as funções maternas (handling, holding e apresentação de objetos) como fundamentais para que o bebê inicie e dê continuidade ao seu processo, natural/humano, de desenvolvimento emocional.

Por seu turno, evidenciando as funções maternas como essenciais, em "Preocupação materna primária", Winnicott (1956/2000a) enfatiza que o modo como cada mãe exerce suas funções está implicitamente relacionado à sua capacidade de identificar-se a seu bebê e poder, a partir daí, reconhecer quais são suas necessidades basilares e satisfazê-las. Inicialmente, quase que completamente e, aos poucos, na medida em que o bebê vai amadurecendo, ir retirando-se de cena conforme a capacidade do bebê em tolerar esse afastamento. Este movimento se refere à passagem para uma nova fase do desenvolvimento emocional, não mais de dependência total, mas de uma dependência relativa, em que a criança, embora se perceba diferente de sua mãe, ainda precisa contar com sua presença segura para buscá-la e encontrá-la quando necessário. Em ambas as fases, importa notar que a mãe auxilia o ego de seu filho a lidar com as tarefas subjetivas que lhe são impostas a executar em seu processo de desenvolvimento. Esse auxílio materno tem como objetivo tornar a criança cada vez mais confiante de suas capacidades emocionais. No entanto, assegura o autor, em ambas as fases, a mãe está presente de forma a sustentar as conquistas emocionais de seu filho. $\mathrm{Se}$, inicialmente, a ele cabe a difícil tarefa de integrar as experiências vivenciais as quais vão permitindo que um contorno egóico e corporal seja efetuado, nessas operações, o bebê não está sozinho. A mãe estará lá, facilitando (em diversos matizes) essa jornada. A ideia é que, em um determinado momento do desenvolvimento emocional, a criança possa prescindir de sua presença real para se sentir segura o suficiente para lidar com as situações que o viver impõe. Nesse momento, poderíamos dizer que o desenvolvimento emocional alcançou sua última etapa, rumo à independência, a qual, é claro, não se completa em totalidade e suporta idas e vindas, recuos e reconquistas ao longo de toda vida. 
Aqui, acreditamos que a capacidade de estar só se vincula ao modo de relação estabelecido entre ego e objeto tratado em um dos últimos artigos de Winnicott (1989/2007), intitulado "O uso do objeto no contexto de Moisés e do monoteísmo". O mais interessante, nesse artigo, é que, de uma forma pouco usual em sua obra, Winnicott chama a atenção para a importância da presença paterna sustentando essas operações. Em sua opinião, o pai se apresenta como o primeiro objeto total em destaque às parcialidades mãe/bebê e, por essa razão, pode ser usado pelo bebê como protótipo na construção de sua própria unidade singular. A partir disso, o autor, ressalta que o uso do objeto se distingue tanto do modo onipotente de relacionamento com os objetos subjetivos primitivos quanto com os objetos objetivamente percebidos, já que nesses a matriz utilizada para a relação é perpassada pelos mecanismos subjetivos (projeções e fantasias) do ego. Para Winnicott (1989/2007), usar o objeto pressupõe que o ego esteja percebendo a externalidade do objeto e aproveite essa percepção para criar algo novo, que carregue aspectos tanto do ego quanto do objeto, sem se confundir inteiramente com nenhum dos dois. Para que tal operação seja realizada, Winnicott adverte que o objeto precisa sobreviver aos intensos e constantes ataques destrutivos que the são imputados pelos investimentos do ego (em fantasia) de forma que, em um momento subsequente, este possa (re)encontrar o objeto sobrevivente (na realidade) e usá-lo em seu processo de criação e manipulação dos mundos interno e externo. Há, aqui, a construção de uma distância entre ego e objeto, mas há, igualmente, uma ponte transicional que os interliga, mantendo-os, simultaneamente, relacionados e apartados. Nesse estágio do desenvolvimento emocional, o ego pode apreciar estar só, ao lado de outra pessoa, que também se regozija por estar sozinha na presença de alguém. A esse respeito, no artigo de 1958, Winnicott (1958/1982a) oferece, como exemplo, o fato de dois amantes, após a relação sexual, sentirem-se felizes e satisfeitos, cada um sozinho com seus pensamentos e reflexões, ao lado de seu parceiro que também aproveita de sua solidão compartilhada.

Dessa forma, poderíamos afirmar que a capacidade de estar só, para ser alcançada, depende dos modos pelos quais os estágios foram sendo construídos ao longo do processo de desenvolvimento emocional. Do inicial, no qual não há ainda no infante a capacidade de se perceber como um Eu singular, distinto dos demais, imerso na solidão, há, contudo, a presença materna (e paterna) que sustenta a diferença e a singularidade de seu bebê de forma quase que total por meio dos cuidados elementares que dispensa ao seu filho. Podemos supor, então, que a mãe antecipa, para seu bebê, um ego a se desenvolver. Um desenvolvimento que vai se realizando de forma paulatina, até que a criança atinja o estágio em que pode afirmar "Eu sou". Ao afirmar as duas palavras mais perigosas do mundo, segundo Winnicott (1989/2005), em seu artigo "Sum: eu sou", a criança constrói suas fronteiras egóicas, testando suas capacidades criativas, brinca, sozinha na presença de sua mãe para quem pode recorrer todas as vezes em que se sinta ameaçada de ser invadida, quer seja pelos estímulos externos, quer seja por estímulos internos. A mãe empresta, portanto, sua segurança ao prestar auxílio ao ego de seu filho o qual, aos poucos, vai ficando cada vez mais confiante a ponto de prescindir de sua 
presença real. No entanto, afirma o autor, prescindir da presença real não significa que a presença materna não esteja internalizada. Ela estará lá, suficientemente sutil, para ser acessada, quando e caso seja necessário. É essa relação primordial que dotará ao ego a capacidade de apreciar a solidão, pois dessa forma, ainda é mantida a relação com os objetos amorosos (internos e externos) e com o mundo que o cerca, de um modo reflexivo e relaxado, e não defensivo e angustiado.

Ainda no artigo de 1958, Winnicott (1958/1982a) sugere que esse modo de relacionamento que leva a criança ao alcance da capacidade de estar só seja a fonte da relação transferencial. No nosso entendimento, o autor, com essa afirmação, está sugerindo que o tratamento psicanalítico seja capaz de permitir aos pacientes que eles alcancem a capacidade para estarem sozinhos por meio do uso do analista como objeto. Seguindo essa indicação, nos propomos a apresentar, a seguir, dois processos clínicos nos quais, do encontro com a solidão, os pacientes foram construindo recursos emocionais mais sustentáveis que os ajudaram a viver, sozinhos, mas, na presença de alguns semelhantes.

\section{ANNA: DA CONCHA AO ESCUDO}

Há alguns anos, Anna me procurou para análise. Disse-me que havia se mudado, há pouco tempo, para a cidade em que eu trabalhava. Não conhecia ninguém e estava se sentindo muito só. Declara que o que a estava assustando era o retorno de um sentimento que ela pensava haver ultrapassado há anos. Relata que, de tempos em tempos, a vida se esvai de sentido. Os dias passam e ela, às vezes, nem percebe. Nesses momentos, se fecha em sua concha (casa), "assiste" televisão, "come" alguma coisa, tem dias que toma banho, outros não. Somente o choro é o elemento constante. E o vazio.

Aos poucos, vai me fazendo conhecer, na história de sua vida, outras "mudanças" que provocaram momentos bastante desorganizadores como o atual. Conta-me que era nativa de uma pequena cidade do interior do Estado. Teve que se mudar para um centro urbano maior para concluir os estudos fundamental e médio em um colégio interno. À época, contava com 12 anos. As lembranças que tinha desses anos eram ambivalentes. Algumas felizes, geralmente ligadas a situações com colegas da escola. E outras tristes, posto que houve inúmeros momentos em que as amigas retornavam para suas casas, em alguns feriados, e Anna ficava sozinha, sentindo-se abandonada naquele grande espaço escolar vazio.

A solidão e o vazio se combinavam com as lembranças sobre as idas e os retornos entre o internato e a casa de seus pais. Quando o ônibus chegava em sua cidade natal, pensava - "será que dessa vez alguém estará me esperando?" Ninguém. O mesmo ocorria quando tinha que embarcar de volta ao colégio. Todos muito ocupados para acompanhá-la à rodoviária, que permanecia, dessa forma, vazia.

Anna me afirma que o momento mais difícil de enfrentar foi a mudança de Estado, após a graduação. Apesar de ter sido devido a uma boa oportunidade de trabalho, que ela aceitou e aproveitou, dias e dias foram gastos no desespero. Resolveu 
procurar ajuda profissional quando, em um dia que se encontrava sozinha em casa, um pensamento, como um raio, Ihe passou pela cabeça: - "eu posso morrer aqui dentro e só vão achar meu corpo semanas depois quando os vizinhos chamarem o porteiro para ver que cheiro horrível seria esse!!!!!"

O trabalho psicoterapêutico, naquele momento, foi extremamente importante. Permitiu-Ihe se recuperar, reiniciar o trabalho, fazer alguns amigos e namorar um rapaz por uns meses. Tudo parecia bem, até que nova oportunidade de trabalho Ihe foi apresentada. Acreditando estar bem emocionalmente, mudou de Estado novamente. Nesse momento, ao perceber que os mesmos sentimentos de solidão e desespero começavam a brotar, procurou-me para iniciar um trabalho analítico.

Em sua primeira entrevista, uma contradição me chamou a atenção. Anna parecia à vontade em contar sua história, fazer algumas conexões, suposições e descrições ricas em detalhes. Por outro lado, nada, em sua maneira de se apresentar, demonstrava grande sofrimento. Até mesmo quando relatava os momentos mais difíceis e angustiantes pelos quais passara. Tal sentimento me dava a impressão que estava falando de uma terceira pessoa e não dela mesma. Um relato apartado do afeto. De forma semelhante, as conquistas e os sucessos, tanto profissionais quanto afetivos, também não eram aproveitados como se fossem seus. Tudo ficava meio que em um limbo..

Dessa primeira entrevista, iniciamos um trabalho clínico com duas sessões semanais. Fui percebendo que quanto mais o atendimento progredia, no sentido de Anna ir estabelecendo comigo uma relação transferencial de confiança e segurança, mais a angústia e a solidão ameaçavam a invadir. Por um lado, eu percebia que as sessões funcionavam como um porto seguro e fiável que a ajudava a se organizar frente às exigências desconcertantes impostas pela necessidade de se instalar em uma nova cidade e em um novo emprego. Por outro lado, o próprio trabalho clínico e sua proposta em retomar experiências do passado que se ligam às vivências atuais, as associando, conectando e ressignificando impunha, igualmente, a desorganização. Lembro que a imagem e a canção de Humpty Dumpty, personagem de Lewis Carroll (1872/2009), andando sobre o estreito muro era constante em minha cabeça.

\section{"Humpty Dumpty sentou-se em um muro}

Humpty Dumpty caiu no chão duro

E todos os homens e cavalos do rei

Não conseguiram juntá-lo outra vez!" (Benedito \& Pinheiro, 2018, p. 321).

E, assim, eu ponderava qual seria a melhor estratégia a ser adotada para que a jornada clínica pudesse ser percorrida de forma estável, diante dessa sensação contratransferencial de tamanha fragilidade egóica. Como se qualquer passo em 
falso pudesse ser capaz de fazê-la tombar do muro e se estilhaçar tal qual delicado cristal (Benedito \& Pinheiro, 2018).

Na dúvida, preferia fazer poucas intervenções e suster o ritmo das sessões. Seguia, nessa decisão, uma sugestão do próprio Winnicott (1954/2000b) ao afirmar que ao analista cabe sustentar o processo terapêutico com sua presença viva de forma a abrir o campo de confiabilidade a partir do qual o trabalho clínico possa se processar. Tal sustentação (holding), afirma o autor, deve preceder algumas intervenções clínicas, como as interpretações e as construções. Na minha opinião, a importância desse procedimento baseia-se no fato da confiança ser o pilar da ocorrência de um movimento extremamente valoroso para a condução clínica: a regressão em transferência. Quando esta se fez presente, nesse momento, pude sentir a angústia brotar.

Anna passou a chegar em meu consultório completamente abatida, fatigada, extenuada. Deitava-se no divã e calava-se. Porém, seu desespero gritava a plenos pulmões. Eu o podia escutar e sentir. Quando as sessões acabavam, Anna se levantava, se despedia e eu, invariavelmente, acenava o próximo dia de sessão. Minha intenção era a de afirmar que, a despeito da solidão e isolamento, eu apostava no encontro.

Em termos transferenciais, eu não encontrava ponto para interpretar, desejo recalcado para desvelar, divisão subjetiva para destacar. Igualmente, não havia conflito, dúvida, vergonha, nada. Porém, em termos contratransferenciais, eu podia sentir o que ela não conseguia me dizer em palavras. Eu também sentia a exaustão, a paralisação, a falta de sentido, o vazio. Interpretando esses afetos constratransferenciais como indicativos da trama fantasmática de Anna, decidi levar adiante uma estratégia clínica (Pinheiro, 2017). Tomei, primeiramente, a proposta de Winnicott (1954/2000b) de que, em transferência o paciente nos lança sua questão mais pungente e que esta diz respeito a uma das etapas de seu processo de desenvolvimento emocional. Pensei, então, que o que Anna compartilhava comigo se relacionava a um momento primitivo no qual o estado de dependência absoluta indica que o ego do infante necessita que o ambiente o ampare em suas conquistas. A sensação de falta de ar e de sentido me faziam supor que para Anna, nesses momentos, o próprio ambiente se retraía e não oferecia o suporte necessário ao seu amadurecimento afetivo. Cabia a mim, portanto, como analista, fazer valer o poder do setting (como função ambiente/holding) e estar lá, ouvindo, sentindo, me fazendo presente.

Mas, me pareceu que eu deveria avançar um pouco mais. Decidi antecipar, para Anna, sentidos e significações com as quais ela pudesse se identificar e se contrapor. Embora eu nada verbalizasse em palavras, enquanto ela passava as sessões em silêncio, eu repassava, em minha cabeça, o fio de sua história de vida, os planos que ela havia feito, as projeções futuras. Minha intenção era a de manter viva a esperança de que ela vivia. Se o que ela compartilhava comigo era o vazio, tomei o vazio como ponto de início, como argamassa de trabalho. A cada sessão, 
invariavelmente, eu me lembrava dos vazios em que Anna habitara: a escola, o quarto, o pátio do internato, as rodoviárias, os apartamentos, as cidades. Preenchia-os em meu pensamento, de pessoas, movimentos, carros, barulho, conversas. Minha intenção, nesses momentos, era manter em andamento o trabalho psíquico de investimento. De alguma forma, eu produzia, por ela, o aproveitamento da energia pulsional que se esvaía sem encontrar ponto de estofo e de contorno. Talvez, para não sucumbir ao vácuo que assolava as sessões.

Após alguns meses de análise, Anna começou a faltar. Disse-me que sentia que estava acontecendo, na análise, o mesmo que ocorria em sua vida: tudo perde o sentido. $E$, por isso, ela se fechava, se isolava, e não deixava que nada a pudesse atingir. Assim, somente assim, sentia-se segura, enclausurada em sua concha. Expliquei-lhe que geralmente isso ocorre nos atendimentos psicanalíticos. O importante era que, uma vez que a situação se repetisse no espaço clínico, ganhávamos oportunidades de melhor entendê-la e modificá-la. Destaquei, nesse momento, que, pela primeira vez, ela estava sentindo tudo isso, na presença de alguém. Anna nada respondeu e as faltas continuaram.

Porém, alguns meses adiante, algo novo começou a acontecer. As vezes em que Anna não vinha para as sessões, ela me ligava. Telefonava para explicar as razões de sua impossibilidade em comparecer naquele dia. Conversávamos um pouco e marcávamos a próxima sessão. Comecei a aguardar seus telefonemas. Percebi que eles, de uma forma inusitada, me permitiam produzir algum trabalho clínico. Ao longo das ligações, eu perguntava algumas coisas, relacionava outras, pedia que ela me explicasse melhor tal e qual experiências e vivências. Comecei a perceber, então, que um elo havia se estabelecido entre nós. Que mesmo ausente, fisicamente, Anna se fazia presente por meio das chamadas. Um fio de comunicação. Apostei nisso e mantive esse modo inusitado de conduzir o trabalho clínico alternando as sessões presenciais com as por telefone.

Claro que eu observava a ambiguidade dessa situação. Podia sentir a potência dos impulsos destrutivos de forma pungente. Percebia que o trabalho clínico estava sempre sob o fio da navalha, pois, nos dias em que ela se apresentava presencialmente, o silêncio preenchia a sala. Deitada no divã. Fechada em sua concha. Protegia-se das factíveis invasões. Por outro lado, nas ligações telefônicas, as pausas eram longas e as palavras escassas. No entanto, baseei-me, novamente, na teoria para melhor entender e conduzir esse movimento clínico.

Parti do princípio que, no início da vida, à mãe cabe receber e sustentar (holding) a agressividade primária de seu bebê. Esse potencial agressivo primitivo, sendo inerente à motilidade dos seres vivos, segundo Winnicott (1989/2007), não possui intenção deletéria. No entanto, alerta o autor, apesar da não intencionalidade, o caráter destrutivo do impulso primitivo pode ocorrer caso o objeto, que o recebe, não sobreviva a seu impacto. Em sua perspectiva, cabe à mãe a tarefa de sobreviver ao potencial explosivo inerente ao impulso primitivo. É essa sobrevivência que permite que eles sejam acolhidos, contornados, erotizados e significados. Nesse 
movimento, a potência destrutiva ganha estatuto criativo, na medida em que comparece no processo de construção dos mundos interno e externo. Em termos clínicos, pela regressão em transferência, cabe ao analista, refundar, em alguma medida essa função materna. E sobreviver. Para, com isso, abrir um espaço de conciliação, de negociação, de transição, que endereça da destrutividade, em potência, à criatividade, em ação (Pinheiro, 2018).

Após um longo período, um novo movimento começou a se apresentar. As faltas se tornaram menos frequentes. E, esporadicamente, Anna começou a trazer, às sessões, algo para comermos juntas. Pão de queijo, um pedaço de bolo, sanduiches, que ela preparava especialmente para essas ocasiões. Tal gesto me lembrava as brincadeiras infantis de fazer comidinha e levar para os adultos provarem. Apostei que Anna, dessa forma, começava a "brincar", sozinha em sua casa. Porém, "na presença de alguém", posto que a mim ela se endereçava, alcançava e compartilhava suas "produções" de forma regular e necessária (Winnicott, 1958/1982a).

Ao longo desse novo dispositivo clínico, fui percebendo que algo fundamental estava se estabelecendo. Apesar das sessões permanecerem silenciosas, podia sentir nitidamente que o vazio entre nós duas havia sido preenchido. Que compartilhávamos as composições efetuadas no espaço clínico. Comuniquei a ela essa minha sensação. Anna me olhou longamente e concordou. Disse-me que embora não soubesse explicar o porquê, percebia que ainda se sentia sozinha, mas não mais desesperada. Perguntei: - "saiu da concha?" - "Sim, acho que sim. Me parece que agora, basta um escudo...".

\section{LUNA: DO VAZIO À XÍCARA DE CHÁ E UM SONHO}

Há cinco anos, Luna não era minha cliente. Ela era uma de minhas alunas do noturno, as aulas que eu ministrava eram das 18:30 às 22:00. Jamais se atrasou, jamais deixou de fazer nada ou de cumprir qualquer tarefa. Criativa, trazia para a sala de aula maneiras muito originais e lúdicas para apresentar os temas de psicologia, psicopedagogia, jogos e brincadeiras, psicanálise, disciplinas que por 11 anos ministrei na Faculdade de Educação de uma universidade pública da cidade do Rio de janeiro.

Luna passou de aluna à monitora e sempre foi exemplar na execução de suas tarefas e na criação de materiais para o melhor aproveitamento das aulas pelos colegas que ainda não haviam cursado a mesma. Jamais se atrasava ou faltava, mesmo sendo as aulas à noite, Luna gostava da noite, dizia-me. Um dia, em final de semestre, tendo sido montado todo um material de avaliação processual para esta turma, Luna não aparece. Espero, atraso para entrar em sala, a lua estava no céu, mas Luna, que jamais se atrasava, não chegou.

Precisando do material, ligo para o celular da mesma e, quando ela o atende, eu pergunto se ela estava chegando. A resposta me impacta e eu ouço a seguinte explicação: "Obrigada por ligar, professora, eu ia continuar a me cortar, mas como 
era o seu número eu atendi o celular". No mesmo momento, começo a conversar com Luna, atraso a aula, peço que ela me mande fotos do corte que poderia ter chegado ao pulso, do curativo e do objeto cortante usado e igualmente digo que entraria na sala e diria que eu havia esquecido o material e que faríamos uma revisão para a avaliação neste dia e, na outra semana, teríamos a avaliação.

Quando entro no carro para voltar para casa, antes ligo para Luna e ela pede para, em outro dia, conversar. Recebo Luna no espaço precário existente na faculdade e ouço dela muitas coisas, dentre elas uma revelação que jamais percebera na lida da sala de aula nem nas disciplinas que ela fizera comigo. Indaga-me: "A senhora nunca reparou nas minhas tatuagens nos braços?". Respondo-lhe que sim e que eram lindas! Ela, então, me conta a história das lindas tatuagens, elas escondiam cortes simétricos nos braços e nas pernas, sempre feitos quando a dor de existir era insuportável. Estávamos sentadas no chão sujo da sala, eu a olhei e falei a ela: "Se você quiser ajuda, eu posso tentar ajudar". Ela respira fundo e diz a mim que, como confiava em mim, ela aceitaria ajuda. Chega o final do semestre e passo a ver Luna semanalmente no consultório em atendimento social e consigo que um amigo psiquiatra a veja igualmente, e ele passa a dar a ela todos os remédios necessários para se tratar e eu mantenho a terapia. Tal fato aconteceu em 2014. Hoje, em 2020, resolvi escrever sobre minhas anotações e lembranças além dos escritos de Luna dados a mim ao longo destes anos e de quadros pintados por ela no ano de 2019.

Bollas (2013), ao estudar os broken selves, complementa os estudos de Winnicott sobre a questão do medo do colapso e afirma que:

O efeito da pessoa colapsada é significativamente reduzido. Eles raramente demonstram emoção e não sentem raiva, ansiedade ou euforia por eventos na vida. Em vez disso, mantém uma constante neutralização das mudanças afetivas; nada vale o esforço. [...] Winnicott pode sugerir que o falso self está protegendo um remanescente do verdadeiro self. Eu acho que esse self escondido é um fantasma; um triste representante do que a pessoa pensou que se tornaria. [...] Esses pacientes formam uma espécie de transferência neutra para com o clínico, uma transferência que expressa sua reestruturação negativa e os analistas sentem que estão navegando na água e não estão indo a lugar algum (pp. 16-17).

Quando Bollas (2013) enfatiza sua forma de olhar a questão do colapso, das agonias impensáveis nas estruturas primitivas de desenvolvimento que se partem antes de poderem de fato existir, ele, de certa forma, discorda de Winnicott ao dizer que no centro deste ser partido, colapsado, há "um self escondido, um fantasma; um triste representante do que a pessoa pensou que se tornaria" (p. 17) e não um resquício de verdadeiro self. 
Devo, no caso de Luna, concordar com Bollas (2013), já que a ideia de fantasma em frangalhos como sendo si mesmo ou o buraco ou o vazio como representação do que existe dentro de si, é real, principalmente quando tudo está escuro e essas pessoas não conseguem sequer chorar. Não vale à pena, dizem, já que nada melhora, só piora ou não muda nada.

Se há algumas palavras que acompanharam e ainda são ditas nas falas e dor extrema de Luna são vazio, solidão, abandono e o nada. Este caso é uma reflexão sobre esses temas, mais especificamente a questão do cair para sempre ou agonias impensáveis como Winnicott denomina alguns dos aspectos da psicose que advém quando tudo corre mal, ou basicamente tudo.

Um ponto que muito bem demarca Winnicott em sua obra é a questão do falso self que emerge como proteção a um resquício de verdadeiro self quase aterrado pelas muitas falhas do ambiente. Luna cumpria o ritual de ir para a faculdade, ser a melhor aluna da sala, mas sempre estava sozinha, não gostava de trabalhos em grupo e, se tinha de fazê-los, acabava fazendo pelos outros o trabalho e o apresentava. Quem era Luna? Na verdade, para os professores ela era uma aluna exemplar, até demais. Para os colegas, alguém que era nerd e que seria boa colega de grupo para se passar de ano. Luna morava com Paulo, com o qual se casaria anos depois. Segundo ela, o marido a mantinha viva. $\mathrm{Na}$ época, não entendi essa frase, já que via Luna somente na hora da aula ou, depois, como minha monitora.

Em 2019, Luna precisa apresentar uma declaração minha sobre os fatos que aconteceram desde ela pequena com relação ao abuso paterno e ao abandono e desamparo materno em relação a ela. Foram dias e dias a recordar, ela com seu diário e memórias jamais esquecidas e eu com minhas muitas anotações, o doloroso percurso de sobrevivência de Luna ao sol tenebroso que cega qualquer um e queima o corpo e a alma que foi sua vida até ela ir morar com seu marido. 0 que em parte a protegeu do genitor, mas não da mãe. Hoje, Luna já se protege igualmente da toxidade materna.

Recebi de Luna, no fim do ano de 2019, um livro da obra completa poética de Gullar (2015) com uma dedicatória escrita em caneta dourada na capa preta, um cartão de uma fadinha segurando uma lanterna onde havia o seguinte escrito "Sol, que 2020 seja feliz!" Em um marcador de livro com flamingos voando e dois no lago com um céu azul, encontro "Sol, boas aventuras e bons sonhos". A poesia escolhida por Luna para a dedicatória foi "Internação", com a seguinte dedicatória

Sol, Obrigada por todo o tempo me ajudar a sair do fundo escuro da minha alma, obrigada por me ajudar a viver o sonho do vento no rosto. Obrigada pela minha liberdade e por me ajudar a vivêla. Que esse livro possa te fazer sonhar acordada e que as palavras te preencham de emoções, vida e compreensão. Que 2020 venha para que os sonhos possam ser vividos! Bjos Luna (2019) 
Utilizando a metáfora de "mesmo par de óculos", Winnicott (1994/1963), em "Medo do colapso", introduz a questão do vazio, antes enunciada por ele no início do artigo em questão. Muito significativo neste desenvolvimento do tema vazio associado ao tema morte e ao medo do colapso já acontecido, mas jamais experienciado, é o fato de ser repetido, em cada sessão, que todos esses não experienciamentos precisam ser vividos. Indo mais adiante, o mesmo autor relata:

Em alguns pacientes, o vazio precisa ser experienciado, e este vazio pertence ao passado, ao tempo que precedeu o grau de maturidade que tornaria possível ao vazio ser experienciado. Para entender isto, é necessário pensar não em traumas, mas em nada acontecendo quando algo poderia proveitosamente ter acontecido. É mais fácil para um paciente lembrar um trauma do que nada acontecendo quando poderia ter acontecido. $\mathrm{Na}$ ocasião, ele não sabia o que poderia ter acontecido e, assim, não poderia experienciar nada, exceto notar que algo poderia ter sido (p. 75).

Em janeiro deste ano, ou seja, 2020, Luna chega e pergunta, perto do fim da sessão, se eu já tinha visto o filme "O Coringa". Disse-lhe que não. Ela, então, me afirma que ela e o Coringa, em muitas partes deste filme, pensam igual, ele deu voz ao que ela sentira sempre, se identificou com sua invisibilidade e com a questão de ninguém perceber que o sistema era totalmente inadequado para cuidar dele. Neste momento, ela abre o caderno onde anota suas coisas, pensadas ou vividas, ou quase sempre vistas em um filme que passa e repassa em sua mente como um pensamento repleto de vozes e cenas que ela já sabe e já viu em algum lugar, não sabendo ela se esse saber foi ela quem inventou ou viveu de verdade. Lê para mim a seguinte fala do personagem, aliás duas falas: "a pior parte de ter uma doença mental é que as pessoas esperam que você se comporte como não a tivesse" e "Durante toda a minha vida, eu nem sabia se eu realmente existia. Mas eu existo", e acrescentou "mesmo que ninguém perceba, diferente do Coringa".

Abreu (2013, p. 27), em seu livro "Menina amarrotada", conta que "lá vinha o Nunca pra amarrotar a menina outra vez. Uma roupinha dentro de mala cheia". Assim via Luna, roupinha amarrotada num mar de vazios cheios demais de dores. Essas dores eram primeiro contadas a mim no nada, no choro que preenchia a sensação de vazio que eu sentia dentro de mim assim como a sensação de impotência. Faltava a ela e a seu marido tudo, emprego, dinheiro, casa. Morava em um antigo quarto de empregada pequeno da casa de sua avó - a parte que lhe deram no latifúndio familiar. Ao longo desses anos todos de atendimentos presenciais, escritos no WhatsApp, fotos de cortes, dos cachorrinhos dela, da confusão da casa onde nada cabia enviadas em horários por mim permitidos quando eu já dormira (Luna gostava da noite e do silêncio da noite), fui tecendo a vida de Luna com o que ela era capaz de lembrar. Solidão era algo que ela sempre marcou, assim como a vontade real de ir embora daqui deste mundo, ou seja, se matar. 
Luna sempre me contou como ela se mataria, como ela mataria todos que irritavam a ela a partir de frases que ela ouvira sempre da família e de colegas da faculdade, iguais as que o Coringa ouviu ao longo da vida. Numa sessão, ela me entregou a lista do que ela pensara naquele dia de como poderia se matar e afirmou: "Sol, desta vez eu só pensei, eu não me cortei, não quis me jogar na frente do ônibus, não quis me jogar no trilho do metrô, desta vez eu só escrevi e trouxe para você".

Como esta lista, possuo comigo muitas outras que ela escreveu e escreve. Possuo seus escritos de quando eu não a conhecia. Ela me deu todos eles para que eu lesse e para eu os guardasse para ficarem longe daquele que ela tomou coragem de processar depois de adulta, o seu genitor que a abusou desde criança.

Como escreve Abreu (2013), em seu livro "Menina amarrotada", Luna passou o tempo de sua vida sendo quem ela não era por dentro, sempre pronta a ajudar qualquer pessoa, mesmo que ela não tenha sido ajudada ou acalentada. Ela acreditara que era amada até perceber, e isso foi recente em seu processo analítico, que ela teria de ser qualquer coisa menos ela, senão ela poderia não ser mais nada. E assim, que nem a protagonista do livro de Abreu (2013), Luna foi se amarrotando virando uma dobradura quase que minúscula.

Havia poucos momentos em que ela não se transformava em algo minúsculo de tão amarrotada, um deles era o chá. A tia dela se mata e ela limpa a casa desta tia muito amada e a ela foi dado o direito, com muitas restrições por parte da avó, que ela saísse do quarto de empregada e fosse morar na casa desta tia. Nela, Luna, numa das noites em que arrumava o que era de sua tia e que sua avó não quisera, nem suas tias, nem suas primas e primos, ela acha duas xícaras de chá. Luna ama chá e faz coleção de canecas para chá - são 4 . Um dia ela me pergunta se queria tomar chá, ela traria os biscoitos. Respondo que sim e na outra semana ela traz, muito bem embrulhado em sua mochila as duas xícaras de chá e um pequeno pacote de biscoitos da padaria que ela ama perto de sua casa. Passa a ser um momento bom dentro de uma história de vida muito difícil, quase que impossível de ter sido vivida.

Vem a quarentena, passamos a falar por uma tela e Luna marca que, na verdade, o que é difícil para os outros, ficar isolado, para ela sempre foi fácil, já que, ela odeia gente, odeia multidão, odeia... odeia tudo aquilo que chamamos de vida normal. Para Luna, esse normal é uma dor sem fim. Como me disse, "as pessoas pensam que eu estou bem, as pessoas pensam que eu gosto delas, as pessoas pensam tantas coisas sobre mim que eu não sou porque todos são como um mar parado, poucas fazem alguma marola na minha vida, você e o Léo fazem, para as demais é nada, eu não sei sentir nada." Em seu livro, "De que cor será sentir? - método psicanalítico na psicose", Costa (2016), na abertura do mesmo, escolhe uma pintura de Picasso (1903), "Os desamparados", para marcar de que lugar o olhar da autora perpassa. Sua dedicatória é "A todos aqueles cujo abandono induziu à clivagem".

A partir deste ponto iniciamos quase que um jogo que, se antes era muito difícil, passou a ser menos pesado. O contar os sonhos/pesadelos diários que Luna tinha. 
Não que ela não falasse deles, mas eles eram uma parte na parte do choro e do relato ou revivência de fatos tenebrosos que iam do abuso paterno ao abandono materno e às maldades vividas na família e fora dela. De novo, uma menina amarrotada.

No mês de maio, Luna me escreve no WhatsApp: "você está bem?". Sim estava, íamos ter sessão de tarde. Ela acrescenta: "sonhei com você, mas fica calma que não morreu ninguém, nem você". Noto que algo muda nos sonhos/pesadelos de Luna, ela não matara, não morrera, ninguém morrera. No nosso horário, ela me conta o sonho e afirma, não foi pesadelo desta vez!

De repente estava numa confeitaria como a Colombo, mas eu sabia que não era a Colombo. Um homem me empurra e coloca na minha mão dois cartões de crédito, não sei o motivo, mas coloca e me empurra para dentro da confeitaria. Eu penso, mas como vou encontrar a Sol? Digo, moço, não preciso nem quero seus cartões, mas ele insiste, diz para a atendente que os cartões pagariam tudo e ela me leva para escolher uma mesa. Cada mesa que eu escolhida, do nada aparecia uma pessoa nela e doces lindos. Fui a muitas mesas, queria uma que não ficasse no meio do barulho, mas sempre a mesa, quando eu chegava para sentar aparecia outra pessoa sentada. Até que consegui uma e você chegou. O barulho continuou, mas ficou muito menor. Eu pedi para nós todos os doces lindos que eu tinha visto nas mesas. Tomamos chá e comemos os doces. Quando peço a conta, certa de que não poderia usar os cartões porque não sabia a senha, a atendente nos diz que a conta já estava paga. Marcamos outro chá e eu acordo.

Luna, depois dessa narrativa onde ela sorria, uma das poucas vezes que a vi sorrir em uma sessão, diz a mim que achava que esse sonho queria dizer que ela gostava de mim, já que aguentou o barulho e que depois ela pode conversar comigo como não consegue conversar com ninguém na vida dela, pois eu consigo ouvir o que ela pensa, quer fazer ou faz, como se machucar e não julgo seus pensamentos nem atos. No fim, afirma: "Eu gosto de você, Sol".

Quando Bollas (2013) nos marca que "esses pacientes formam uma espécie de transferência neutra para com o clínico, uma transferência que expressa sua reestruturação negativa e os analistas sentem que estão navegando na água e não estão indo a lugar algum" (pp. 16-17), garanto que esta é a sensação que muitas vezes tenho de somente estar ali, "navegando na água e não indo a lugar algum". Acredito, entretanto, que mesmo não havendo a percepção do analista de onde ele está chegando ou sendo útil no processo de costura do fantasma em frangalhos, algo fazemos, somente pelo fato de estarmos ali, ou seja, na revivência do abandono e do desamparo há alguém sustentando tanto o vazio quanto o buraco, como uma corda que tenta puxar o cliente para um lugar onde um pouco 
de ar possa ser respirado antes de ele submergir mais uma vez e ter a certeza que, como o fio de Ariadne, seremos esse fio que os fazem sair do labirinto escuro deles próprios e poderem respirar.

\section{CONSIDERAÇÕES}

A disseminação do novo coronavírus implementou, no mundo, um estado de alerta no qual o distanciamento social foi indicado como um dos procedimentos adequados ao enfrentamento da pandemia. A partir daí, inúmeros foram os relatos sobre a dificuldade individual de lidar com a solidão. Para muitas pessoas, estar em isolamento foi disparador de sensações desagradáveis como a angústia, o desespero e o desamparo.

Objetivando promover uma reflexão sobre esse fato, fomos endereçadas à proposta de Winnicott sobre o processo de construção subjetiva. Tal recurso teórico nos pareceu pertinente posto que em sua proposição, o autor destaca a existência de uma importante transição, na marcha do desenvolvimento emocional, do estado de solidão primordial à uma capacidade de se estar sozinho, na presença de alguém. Nessa passagem, o autor demarca a necessidade de que alguém realmente esteja presente, inicialmente na realidade factual, para que possa, posteriormente, se fazer presente na fantasia, ou seja, no mundo interno da criança. Podemos supor que esse alguém seja o olhar materno, em sua essência. Olhar que ao acompanhar, ao longo da vida de cada indivíduo, é capaz de oferecer a ilusória certeza que, no fundo, há um lugar para onde retornar quando algumas coisas andam um pouco mal.

Porém, conforme a clínica nos demonstra, muitas pessoas não encontraram estofo para procederem o alcance dessa conquista no desenvolvimento emocional. Para elas, o vazio e o desamparo foram as bases que sustentaram seu processo de subjetivação. Dessa maneira, ficar só é capaz de produzir um retorno afetivo a essas sensações primitivas, como nos dois casos que trouxemos à discussão no presente artigo, quer seja pela via do isolamento radical executado por Anna, quer seja pelos cortes e desespero de Luna.

No entanto, o que gostaríamos de demarcar, igualmente, é que a essas pessoas é dada, algumas vezes, outra chance de reviver ou viver os traumas que lhe deixaram marcas profundas. Essa chance, neste artigo, foi evidenciada na relação transferencial entre analista-analisando nos dois casos descritos. Dessa forma, em nossa percepção, a presença constante e viva do analista, permite que na revivência, pelo analisante, do abandono e do desamparo, haja alguém sustentando tanto o vazio quanto o buraco de seu estofo primitivo. Nesse sentido, a presença do analista mimetiza uma corda que tenta puxar o paciente para um lugar onde um pouco de ar possa ser respirado antes de ele submergir mais uma vez. Assim, em alguns casos, a solidão pode ser vivida como o momento que antecede o encontro e não aquilo que endereça ao abismo. 


\section{REFERÊNCIAS}

Abreu, A. (2013). A menina amarrotada. São Paulo, SP: Jujuba.

Benedito, M. B. \& Pinheiro, N. (2018). Ambiente e integração no processo de desenvolvimento emocional: Reflexões a partir do trabalho com crianças em situação de risco psicossocial. Tempo Psicanalítico, 50(2), 309-329. Disponível em http://pepsic.bvsalud.org/scielo.php?script=sci arttext\&pid=S0101483820180002000168 lng $=p t \&$ tlng $=p t$

Bollas, C. (2013). Catch them before they fall: The psychoanalysis of breakdown. London/New York: Routledge.

Carroll, L. (2009). Através do espelho e o que Alice encontrou por lá (M. L. X. A. Borges, Trad.). Rio de Janeiro, RJ: Jorge Zahar. (Trabalho original publicado em 1872)

Gullar, F. (2015). Toda poesia (21 a ed.). Rio de Janeiro, RJ: José Olympio.

Pinheiro, N. (2017). Sob o fio do paradoxo: A contratransferência como resistência e instrumento clínico. Polêm!ca, 17(4), 1-16. https://doi.org/10.12957/polemica.2017.34308

Pinheiro, N. (2018). Entre a criação e a destruição de mundos: A sobrevivência do analista como metáfora ilusória da (in)consistência egóica do paciente. In I. Motta, A. Rosal, \& C. Silva (Orgs.), Psicologia: Relações com o contemporâneo (pp. 277-289). São Paulo, SP: Ideias e Letras.

Winnicott, D. W. (1982a). A capacidade para estar só (I. C. S. Ortiz, Trad.). In D. W. Winnicott (Org.), O ambiente e os processos de maturação (pp. 31-37). Porto Alegre, RS: Artes Médicas. (Trabalho original publicado em 1958)

Winnicott, D. W. (1982b). Teoria do relacionamento paterno-infantil (I. C. S. Ortiz, Trad.). In D. W. Winnicott (Org.), O ambiente e os processos de maturação (pp. 38-54). Porto Alegre, RS: Artes Médicas. (Trabalho original publicado em 1960)

Winnicott, D. W. (1994). O medo do colapso (J. O. A. Abreu, Trad.). In C. Winnicott, R. Shepherd, \& M. Davis (Orgs.), Explorações psicanalíticas - D. W. Winnicott (pp. 70-76). Porto Alegre, RS: Artes Médicas. (Trabalho original publicado em 1963)

Winnicott, D. W. (2000a). A preocupação materna primária (D. Bogomoletz, Trad.). In D. W. Winnicott (Org.), Da Pediatria à Psicanálise: Obras escolhidas (pp. 399-405). Rio de Janeiro, RJ: Imago. (Trabalho original publicado em 1956)

Winnicott, D. W. (2000b). Aspectos clínicos e metapsicológicos da regressão no contexto psicanalítico (D. Bogomoletz, Trad.). In D. W. Winnicott (Org.), Da pediatria à Psicanálise: Obras Escolhidas (pp. 374-392). Rio de Janeiro, RJ: Imago. (Trabalho original publicado em 1954)

Winnicott, D. W. (2005). Sum: Eu sou (P. Sandler, Trad.). In D. W. Winnicott (Org.), Tudo começa em casa (pp. 41-51). São Paulo, SP: Martins Fontes. (Trabalho original publicado em 1989)

Winnicott, D. W. (2007). O uso do objeto no contexto de Moisés e o monoteísmo (J. O. A. Abreu, Trad.). In C. Winnicott, R. Shepherd, \& M. Davis (Orgs.), Explorações psicanalíticas - D. W. Winnicott (pp. 187-191). Porto Alegre, RS: ArtMed. (Trabalho original publicado em 1989)

\section{CONFLITOS DE INTERESSES}

Não há conflito de interesses.

\section{SOBRE AS AUTORAS}

Nadja Nara Barbosa Pinheiro é Mestre e Doutora em Psicologia (pós-doutorado em Psicanálise e Psicopatologia pela Université Paris VII). Professora Associada da Graduação e do Programa de Pósgraduação em Psicologia da Universidade Federal do Paraná. Coordenadora do Laboratório de Psicanálise/UFPR.

E-mail: nadjanbp@ufpr.br

(iD) https://orcid.org/0000-0003-2927-6177

Maria Vitória Campos Mamede Maia é Professora Associada da UFRJ em Psicologia da Educação, Professora do Programa de Pós-graduação em Educação da UFR, Pós-doutoranda em Design Pedagógico pela PUC/RJ (2019), Doutora em Psicologia Clínica, Mestre em Letras; Coordenadora do 
Espaço de Atendimento Psicopedagógico ao aluno da Faculdade de Educação - UFRJ - EAP e do grupo de pesquisa Criar \& Brincar: o lúdico no processo de ensino-aprendizagem - LUPEA.

E-mail: mariavitoriamaia@gmail.com

(iD) https://orcid.org/000-0002-9697-8243 